\title{
Authenticity Testing of Coconut Toddy Samples (Palm Wine) Using Sulfated Ash Content
}

\author{
Gowri Ramanah", Samantha Wimalasena, Vajira Senadipathi, Eranthi Seniviratne, \\ Kulali Suntharalingam
}

Government Analyst's Department, Sri Lanka

Copyright $\bigcirc 2018$ by authors, all rights reserved. Authors agree that this article remains permanently open access under the terms of the Creative Commons Attribution License 4.0 International License

\begin{abstract}
Coconut toddy (palm wine) is an effervescence beverage tapped from young inflorescence of coconut tree (Cocos nucifera). The sap contains various nutrients, and it undergoes natural fermentative changes when it is stored. Toddy is a traditional alcoholic drink in Sri Lanka. In Sri Lanka artificial fermented liquor is made out from the fermentation of sugar solution. There have been several complaints with respect to adulteration of toddy by artificial fermented liquor. Ash values are used to find out quality, authenticity and purity of substances and these values are important quantitative standards. Hence this study mainly focused on identifying authenticity of toddy using the sulfated ash content. Genuine toddy samples were collected from different areas and artificial fermented liquor samples were made in the laboratory using sugar solution $(16 \%)$ and inoculum of genuine toddy samples. Different ratios of genuine toddy and artificial fermented liquor mixtures were prepared. Sulfated ash content of genuine toddy samples, artificial fermented liquor samples and different ratios of genuine and artificial fermented liquor were determined by using muffle furnace. Linear regression was obtained with sulfated ash content vs different ratios of genuine toddy samples. Sulfated ash content of genuine toddy varied from 0.44 to 0.54 gram $/ 100 \mathrm{ml}$.
\end{abstract}

Keywords Genuine Toddy, Artificial Toddy, Sulfated Ash, Fermentation

\section{Introduction}

Coconut Palm (Cocos nucifera) is an important member of the monocotyledons. This tree mainly grows in tropical coastal areas in Sri Lanka. Coconut is one of the major plantation crops in Sri Lanka which accounts for approximately $12 \%$ of all agricultural produce in Sri Lanka. The coconut sap, an exudate obtained by "tapping" the unopened inflorescence of the coconut palm, is the major raw material used in the manufacture of alcoholic beverages in Sri Lanka. The sap is a brownish clear liquid, containing 14 to 18 percent (w/v) sugars mostly in the form of sucrose. [1]

Toddy is a sweetish, milky white, vigorously effervescent alcoholic beverage consumed as mildly alcoholic beverage similar to beer which is collected from palm tree. [2]

During ancient period, people drank palm wine in early morning in empty stomach before breakfast for health benefits.[2] It is made from the fermented sap of tropical plants of palmate family, such as the coconut palm (Cocos nucifera), oil palm (Elaeis guineesis), date palm, nipa palm, kithul palm and raffia palm (Raphia hookeri).[2]

The coconut sap oozing out of the treated inflorescence is traditionally collected in earthenware pots and allowed to ferment in open pots for varying lengths of time. During this period, microorganisms from the atmosphere contaminate, multiply in the sugary liquid, and finally transform the raw material into various products, mainly alcohol. The resulting solution containing about 7 percent $(\mathrm{v} / \mathrm{v})$ ethyl alcohol is either consumed directly as toddy or distilled to obtain the sprit, arrack. [1]

Distilleries in Sri Lanka usually obtain toddy from contractors in Sri Lanka and they are paid on the content of pure toddy. There have been several complaints with respect to adulterated toddy which is artificially made fermented liquor prepared from sugar solution to the natural toddy.

Therefore, the problem of adulterated toddy has to be solved and necessary steps have to be taken to prevent such substandard toddy entering the market. There have been many research studies about toddy, but none of these studies focused on adulteration of artificial fermented liquor prepared from sugar solution.

Many researchers have studied the chemical or microbiological compounds of fresh inflorescence coconut sap (FICS) and natural fermented coconut inflorescence 
sap (NCIS). The chemical composition of the volatiles from FICS and NCIS which were fermented for $24 \mathrm{~h}$ at 30 $\pm 2^{0} \mathrm{C} ; 21$ compounds making up more than $98 \%$ of the volatiles in FCIS, and 12 compounds representing more than $95 \%$ of the volatiles in NCIS, were characterized[3]. The distribution of microorganisms and changes of physical and chemical contents during the natural fermentation of coconut inflorescence sap and 166 isolates of yeasts and 39 isolates of bacteria were identified, while 17 species of yeasts belonging to eight genera were recorded [7]. The Chemical composition changes of post-harvest coconut inflorescence sap (PCIS) during natural fermentation. Ethanol content increased significantly from 1 to 5 days of fermentation and achieved maximum on the seventh day, but decreased later. After five days total acidity rose sharply and amino acid contents decreased [3]. In "Toddy Authentic or adulterated - How do we Know?" it is explained, as how to identify the starch which is not a component of toddy. The samples were tested with iodine $\left(\mathrm{I}_{2}\right) /$ potassium iodide (KI) reagent and the colour development was compared using analytical grade starch as the control. The microorganisms have the potential of producing many chemical compounds in addition of ethanol. Therefore, there is tendency of giving various colours such as reddish purple and light blue with the presence of amylopectin and amylose, respectively. Light blue colour of the toddy sample was solely due to the presence of the microorganisms introduced from the environment. The samples were tested microscopically to confirm the results. It can be concluded that an adulterated toddy sample gives a deep blue colour with I2/KI reagent due to the presence of starch [1]. However there have been no reports about the adulterated toddy due to presence of sugar.

We studied chemical parameters such as alcohol content, acidity, total solids, sulfated ash, brix value; conductivity and original extract in 4 fresh coconut sap samples which were allowed to spontaneous fermentation and their fermentation were arrested in different time interval. While sulfated ash content remains constant, rest of the chemical parameters were changed with the time during the fermentation processes. Results of sulfated ash content showed in Appendix 2

Hence this study mainly focused on identifying authenticity of toddy using the sulfated ash content. Ash values are used to find out quality, authenticity and purity of substances and these values are important quantitative standards. It provides a measure of the total amount of minerals within a food. Sulfuric acid is added prior to heating to facilitate the destruction of organic matter and to fix certain metals as their sulfate salts to prevent volatilization. When sulfuric acid is used, the resulting material is known as sulfated ash.

\section{Material and Methods}

\subsection{Samples}

This Study involved 90 toddy samples in which fermentation was arrested by adding salicylic acid, received from excise department for quality control purpose and courts for legal action.

Further artificially fermented liquor and 05 mixtures of artificial and natural toddy were prepared in the laboratory.

- 3 samples of genuine toddy directly collected from the tapper in 2014 denoted G1*

- 4 samples of genuine toddy directly collected from the tapper in 2015 denoted G2*

- $\quad 74$ samples of market toddy received from excise department in 2015 denoted MMT

- 8 Samples of toddy received from Courts denoted $\mathrm{CL}$

- $\quad$ Artificial Toddy denoted A*

- 5 Mixtures of toddy and artificial toddy denoted $\mathrm{M}^{*}$

\subsection{Method of Preparation of Artificial Fermented Liquor (Artificial Toddy)}

\section{2.a. Preparations of $16 \%$ Sugar Solution}

$160 \mathrm{~g}$ of sugar was dissolved in 11 tap water in ambient temperature.

\section{2.b. Inoculum}

$750 \mathrm{ml}$ of Suspended toddy i.e. toddy found in the bottom part of tappers pot was collected with the help of excise department.

\section{2.c. NPK as Nutrient}

$0.5 \mathrm{~g}$ of $\mathrm{KH}_{2} \mathrm{PO}_{4}, 0.5 \mathrm{~g}$ of $\mathrm{NH}_{4} \mathrm{CO}_{3}$

2.2.d. Anti-bacterial Agent

$0.5 \mathrm{~g}$ of $\mathrm{Na}_{2} \mathrm{~S}_{2} \mathrm{O}_{5}$

\section{2.e. Preparation of Artificial Fermented Liquor (Artificial Toddy).}

$70 \mathrm{ml}$ of toddy inoculum, NPK nutrients and Antibacterial agent were added to the $16 \% 1000 \mathrm{ml}$ Sugar solution in 2.51 conical flask. Flask was plugged with cotton wool and left for fermentation. At the eighth day maximum alcohol content was obtained. On that day different mixtures of natural and artificial toddy were prepared as shown in table 1.

Table 1. Mixture \% of natural and artificial toddy

\begin{tabular}{|c|c|c|}
\hline Sample no & Toddy $\%(\mathrm{G})$ & Artificial toddy $\%(\mathrm{~A})$ \\
\hline M1 & 100 & - \\
\hline M2 & 75 & 25 \\
\hline M3 & 50 & 50 \\
\hline M4 & 25 & 75 \\
\hline M5 & - & 100 \\
\hline
\end{tabular}




\subsection{Sulfated Ash}

Ten (10) $\mathrm{ml}$ of samples were pipetted out in a silica dish, Five (5) drops of con $\mathrm{H}_{2} \mathrm{SO}_{4}$ were added to the samples and kept for drying on a water bath and heated until they were carbonized by the burner. They were placed in a muffle furnace at $500^{\circ} \mathrm{C} \pm 25^{\circ} \mathrm{C}$. Three (3) drops of con $\mathrm{H}_{2} \mathrm{SO}_{4}$ was added to the samples again and after drying, they were placed in the muffle furnace. Ash weight was determined.

* This process was carried out three times for each sample.

\subsection{Determination of Limit of Detection (LOD) and Limit of Quantitation (LOQ)}

LOD and LOQ were determined based on the standard deviation of the blank. Alcohol content $7 \%$ w/v was prepared using absolute alcohol, was used as blank. Sulfated ash content of the blank samples was determined ten times. Mean and standard deviation (S) were calculated.

$$
\begin{gathered}
\mathrm{LOD}=\text { Mean }+3 * \mathrm{~S} \\
\mathrm{LOQ}=\text { Mean }+10 * \mathrm{~S}
\end{gathered}
$$

\subsection{Calculation of the Amount of Variation Explained by Linear Regression Equation, and its Significance}

SS Sum of square, RSS residual sum of square, Stdev Standard deviation SEM standard error of mean, $R^{2}$ correlation coefficient of degrees of freedom

$$
\text { SStotal }=\sum(\mathrm{Yi}-\overline{\mathrm{Y}})^{2}
$$

$\mathrm{Yi}$ is the value of the dependent $\mathrm{y}$ observed for $\mathrm{Xi}$

$\overline{\mathrm{Y}}$ is the mean value of the dependent $\mathrm{y}$ observed for $\mathrm{n}$ number of observations

$$
\text { SSmodel }=\sum(\mathrm{Ye}-\overline{\mathrm{Y}})^{2}
$$

$\mathrm{Ye}$ is the value of the dependent $\mathrm{y}$ for $\mathrm{Xi}$ the expected on the basis of the linear model

$$
\begin{gathered}
\mathrm{RSS}=\mathrm{SS} \text { total-SS model } \\
\mathrm{R}^{2}=\frac{\text { SSmodel }}{\text { SStotal }} \\
\mathrm{F}=\frac{\mathrm{SSmodel} /(\mathrm{p}-1)}{\mathrm{RSS} /(\mathrm{n}-\mathrm{p})}
\end{gathered}
$$

$\mathrm{n}=$ number of observations

$\mathrm{P}=$ number of parameters estimated in the equation

\subsection{Volatile Organic Compounds}

$25.0 \mathrm{ml}$ of each mixtures were distilled, $0.5 \mu 1$ samples were injected to the Gas chromatograph (Shimadzu 2010, Column RTX $624,30 \mathrm{~m} * 0.32 \mathrm{~mm}, 1.8 \mu \mathrm{m})$ and gas chromatogram were obtained. Gas chromatograms showed in Appendix 3

\section{Results and Discussion}

\section{LOD $0.015 \mathrm{~g} / \mathrm{ml}$, LOQ $0.023 \mathrm{~g} / \mathrm{ml}$, RSD 9.6\%}

Table 2. Mean Sulfated ash content of the Genuine/artificial toddy

\begin{tabular}{|c|c|}
\hline Description & $\% \mathrm{w} / \mathrm{v}$ \\
\hline Sulfated ash content unfermented $\mathrm{sap}^{6}$ & 0.48 \\
\hline Mean of Sulfated ash content of $\mathrm{G}_{1}$ toddy 2014 & $\begin{array}{c}0.47 \pm 0.02(\mathrm{n}=3) \\
(0.46-0.50)\end{array}$ \\
\hline Mean of sulfated ash content of $\mathrm{G}_{2}$ toddy 2015 & $\begin{array}{c}0.50 \pm 0.01(\mathrm{n}=12) \\
(0.48-0.52)\end{array}$ \\
\hline Mean of sulfated ash content of artificial toddy A & $\begin{array}{c}0.13 \pm 0.04(n=3) \\
(0.102-0.183)\end{array}$ \\
\hline
\end{tabular}

The similarity of sulfated ash content of the year 2014 and that of the year 2015 shows the consistency in sulfated ash content of coconut toddy. Further similarity of literature value of the sulfated ash content of unfermented sap is more confirmed the consistency in the sulfated ash content. Sulfated ash content of artificial fermented liquor was significantly low. This show the mineral components are higher in genuine toddy than artificial fermented liquor.

Table 3. Observed and calculated mean sulfated ash content of mixtures of genuine and artificial toddy

\begin{tabular}{|c|c|c|}
\hline \multirow{2}{*}{ Genuine toddy \% in mixture } & \multicolumn{2}{|c|}{ Sulfated ash content $(\% \mathrm{~g} / \mathrm{ml})$} \\
\cline { 2 - 3 } & observed & calculated \\
\hline 0 & 0.13 & 0.12 \\
\hline 25 & 0.22 & 0.23 \\
\hline 50 & 0.33 & 0.32 \\
\hline 75 & 0.42 & 0.43 \\
\hline 100 & 0.54 & 0.53 \\
\hline
\end{tabular}

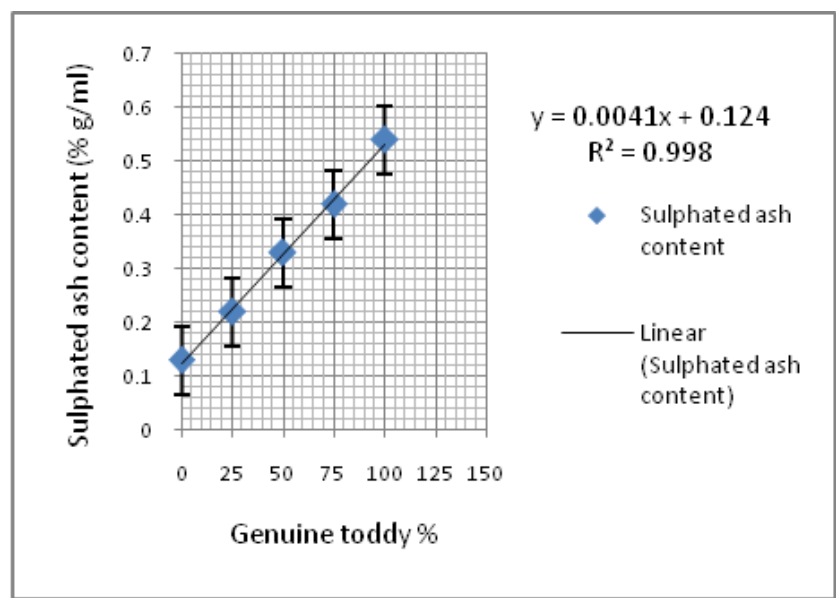

Figure 1. Graph of relation between Genuine toddy (\%)in a mixture of genuine and artificial toddy and their sulfated ash content $(\% \mathrm{~g} / \mathrm{ml})$

Plotting the values (table 3 ) of genuine toddy $\%$ in mixture against sulfated ash content $\%(w / v)$ of the mixtures gives linear relations. (Fig 1) 
$\%$ sulfated ash $=0.0041$ genuine toddy $\%$ in mixture + $0.124\left(\mathrm{R}^{2}=0.998\right)$

The correlation between the genuine toddy \% in mixture at ambient temperature and sulfated ash contents shown in these results indicates the possible influence of mineral components of toddy on its genuine toddy $\%$.

Table 4. Analysis of variance explained by a linear regression equation and its significance (F-test using the $\mathrm{F}$ table)

\begin{tabular}{|c|c|c|}
\hline Statistical Parameters & $\begin{array}{c}\text { Observed sulfated } \\
\text { ash contents }\end{array}$ & $\begin{array}{c}\text { Calculated } \\
\text { Sulfated ash contents }\end{array}$ \\
\hline Mean & 0.328 & 0.328 \\
\hline Std dev & 0.164 & 0.163 \\
\hline SEM & 0.06458 & 0.6452 \\
\hline Number of data points & 0.10428 & $\mathrm{Df}=4$ \\
\hline SS total & 0.10408 & $\mathrm{Df}=1$ \\
\hline SS model & 0.0002 & $\mathrm{Df}=3$ \\
\hline RSS & \multicolumn{2}{|c|}{0.998} \\
\hline R2 & \multicolumn{2}{|c|}{34.12} \\
\hline Fcalculated & \multicolumn{2}{|c|}{} \\
\hline $\begin{array}{c}\text { F critical for } 1 \% \\
\text { significance }\end{array}$ &
\end{tabular}

The calculation of the test table showed that the test for regression was significant while the $\mathrm{F}$ observed value for analyte was much higher than the critical value of 34.1, which corresponded to $\mathrm{F}(1,3,1 \%)$. This meant the sulfated ash content was significantly correlated to the genuine toddy $\%$ in mixture of artificial and genuine toddy. It can be concluded that the regression equation is highly significant $(\mathrm{p}<0.01)$, and explains $\mathrm{r}^{2}=0.998$ of the total variation dataset.

From the observed sulfated ash content, genuine toddy \% in samples were calculated by using the above equation on the samples received from the excise department and courts. From year 2014 and 2015 sulfated ash content and standard deviation, Genuine toddy sulfated ash content vary from 0.44 to $0.54 \% \mathrm{w} / \mathrm{v}$. Furthermore sulfated ash content of artificially fermented liquor varies from 0.102 to 0.183 . Accordingly Samples were classified as genuine $(\mathrm{G})$, adulterated (AD) and artificially fermented liquor (AFM). Sulfated ash content $\% \mathrm{w} / \mathrm{v}$ genuine toddy $\%$ in the sample and classification are shown in Appendix 1. Out of eighty nine samples analyzed from excise and courts, forty two percent $(42 \%)$ were genuine, fifty seven percent $(57 \%)$ were adulterated with artificial fermented liquor and one percent was artificially fermented liquor.

\section{Conclusions}

Sulfated ash content of coconut toddy varies from 0.44 to $0.54 \% \mathrm{w} / \mathrm{v}$. There was a correlation between the genuine toddy $\%$ in mixture at ambient temperature and sulfated ash contents. Linear relations ship shows by this equation, $\%$ sulfated ash $=0.0041$ genuine toddy $\%$ in mixture $+0.124\left(\mathrm{R}^{2}=0.998\right)$. Above Linear regression model can be used to calculate the adulteration of artificial fermented liquor in market toddy.

Limitation:- This equation can be applied only the toddy which is adulterated by artificially fermented liquor prepared by sugar solution.

Recommendation:- further research has to be done on metal analysis, that will help in Authenticity identification of toddy when adulterated other than artificial fermented liquor which prepared by sugar solution.

\section{Acknowledgements}

Authors would like to thank Excise Commissioner General and staff of Excise Department for providing the genuine toddy samples and assistance of laboratory staff.

\section{Appendix 1}

Sulfated ash content $\% \mathrm{w} / \mathrm{v}$, Genuine toddy $\%$ in the sample and classification of samples, G-Genuine, AD- Adulterated, AFM- Artificially fermented liquor

\begin{tabular}{|c|c|c|c|}
\hline Sample no & Sulfated ash content $\% \mathrm{w} / \mathrm{v}$ & Genuine toddy $\%$ in sample & Classification \\
\hline 1 & 0.48 & 86 & $\mathrm{G}$ \\
\hline 2 & 0.40 & 67 & $\mathrm{AD}$ \\
\hline 3 & 0.39 & 64 & $\mathrm{AD}$ \\
\hline 4 & 0.40 & 67 & $\mathrm{AD}$ \\
\hline 5 & 0.39 & 64 & $\mathrm{AD}$ \\
\hline 6 & 0.50 & 91 & $\mathrm{G}$ \\
\hline 7 & 0.50 & 91 & $\mathrm{G}$ \\
\hline 8 & 0.50 & 91 & $\mathrm{G}$ \\
\hline 9 & 0.50 & 91 & $\mathrm{AD}$ \\
\hline 10 & 0.30 & 42 & $\mathrm{G}$ \\
\hline 11 & 0.50 & 91 & $\mathrm{G}$ \\
\hline 12 & 0.50 & 91 & \\
\hline
\end{tabular}




\begin{tabular}{|c|c|c|c|}
\hline 13 & 0.50 & 91 & $\mathrm{G}$ \\
\hline 14 & 0.30 & 42 & $\mathrm{AD}$ \\
\hline 15 & 0.40 & 67 & $\mathrm{AD}$ \\
\hline 16 & 0.40 & 67 & $\mathrm{AD}$ \\
\hline 17 & 0.40 & 67 & $\mathrm{AD}$ \\
\hline 18 & 0.50 & 91 & $\mathrm{G}$ \\
\hline 19 & 0.50 & 91 & $\mathrm{G}$ \\
\hline 20 & 0.50 & 91 & $\mathrm{G}$ \\
\hline 21 & 0.40 & 67 & $\mathrm{AD}$ \\
\hline 22 & 0.45 & 79 & $\mathrm{AD}$ \\
\hline 23 & 0.40 & 67 & $\mathrm{AD}$ \\
\hline 24 & 0.50 & 91 & $\mathrm{G}$ \\
\hline 25 & 0.40 & 67 & $\mathrm{AD}$ \\
\hline 26 & 0.30 & 42 & $\mathrm{AD}$ \\
\hline 27 & 0.40 & 67 & $\mathrm{AD}$ \\
\hline 28 & 0.44 & 77 & $\mathrm{AD}$ \\
\hline 29 & 0.48 & 86 & $\mathrm{AD}$ \\
\hline 30 & 0.50 & 91 & $\mathrm{G}$ \\
\hline 31 & 0.08 & -10 & AFM \\
\hline 32 & 0.23 & 25 & $\mathrm{AD}$ \\
\hline 33 & 0.41 & 69 & $\mathrm{AD}$ \\
\hline 34 & 0.33 & 50 & $\mathrm{AD}$ \\
\hline 35 & 0.25 & 30 & $\mathrm{AD}$ \\
\hline 36 & 0.46 & 81 & $\mathrm{G}$ \\
\hline 37 & 0.42 & 72 & $\mathrm{AD}$ \\
\hline 38 & 0.48 & 86 & $\mathrm{G}$ \\
\hline 39 & 0.33 & 50 & $\mathrm{AD}$ \\
\hline 40 & 0.37 & 60 & $\mathrm{AD}$ \\
\hline 41 & 0.55 & 103 & $\mathrm{G}$ \\
\hline 42 & 0.44 & 77 & $\mathrm{G}$ \\
\hline 43 & 0.44 & 77 & $\mathrm{G}$ \\
\hline 44 & 0.40 & 67 & $\mathrm{AD}$ \\
\hline 45 & 0.38 & 62 & $\mathrm{AD}$ \\
\hline 46 & 0.40 & 67 & $\mathrm{AD}$ \\
\hline 47 & 0.38 & 62 & $\mathrm{AD}$ \\
\hline 48 & 0.29 & 40 & $\mathrm{AD}$ \\
\hline 49 & 0.46 & 81 & $\mathrm{G}$ \\
\hline 50 & 0.51 & 94 & $\mathrm{G}$ \\
\hline 51 & 0.48 & 86 & $\mathrm{G}$ \\
\hline 52 & 0.47 & 84 & $\mathrm{G}$ \\
\hline 53 & 0.39 & 64 & $\mathrm{AD}$ \\
\hline 54 & 0.46 & 81 & $\mathrm{G}$ \\
\hline 55 & 0.49 & 89 & $\mathrm{G}$ \\
\hline 56 & 0.37 & 60 & $\mathrm{AD}$ \\
\hline 57 & 0.36 & 57 & $\mathrm{AD}$ \\
\hline 58 & 0.40 & 67 & $\mathrm{AD}$ \\
\hline 59 & 0.48 & 86 & $\mathrm{G}$ \\
\hline 60 & 0.46 & 81 & $\mathrm{G}$ \\
\hline 61 & 0.46 & 81 & $\mathrm{G}$ \\
\hline 62 & 0.46 & 81 & $\mathrm{G}$ \\
\hline 63 & 0.47 & 84 & $\mathrm{G}$ \\
\hline
\end{tabular}




\begin{tabular}{|c|c|c|c|}
\hline 64 & 0.48 & 86 & G \\
\hline 65 & 0.48 & 86 & $\mathrm{G}$ \\
\hline 66 & 0.40 & 67 & $\mathrm{AD}$ \\
\hline 67 & 0.24 & 28 & $\mathrm{AD}$ \\
\hline 68 & 0.45 & 79 & $\mathrm{G}$ \\
\hline 69 & 0.40 & 67 & $\mathrm{AD}$ \\
\hline 70 & 0.34 & 52 & G \\
\hline 71 & 0.36 & 57 & G \\
\hline 72 & 0.20 & 18 & $\mathrm{AD}$ \\
\hline 73 & 0.20 & 18 & $\mathrm{AD}$ \\
\hline 74 & 0.32 & 47 & $\mathrm{AD}$ \\
\hline 75 & 0.24 & 28 & $\mathrm{AD}$ \\
\hline 76 & 0.29 & 40 & $\mathrm{AD}$ \\
\hline 77 & 0.39 & 64 & $\mathrm{AD}$ \\
\hline 78 & 0.29 & 40 & $\mathrm{AD}$ \\
\hline 79 & 0.41 & 60 & $\mathrm{AD}$ \\
\hline 80 & 0.42 & 72 & $\mathrm{AD}$ \\
\hline 81 & 0.42 & 72 & $\mathrm{AD}$ \\
\hline 82 & 0.32 & 47 & $\mathrm{G}$ \\
\hline 83 & 0.38 & 62 & $\mathrm{G}$ \\
\hline 84 & 0.27 & 35 & $\mathrm{G}$ \\
\hline 85 & 0.55 & 104 & $\mathrm{G}$ \\
\hline 86 & 0.49 & 90 & $\mathrm{G}$ \\
\hline 87 & 0.49 & 90 & $\mathrm{G}$ \\
\hline 88 & 0.49 & 90 & $\mathrm{G}$ \\
\hline 89 & 0.53 & 100 & $\mathrm{G}$ \\
\hline
\end{tabular}

\section{Appendix 2}

\begin{tabular}{|c|c|c|c|c|c|c|c|}
\hline Sample & $\begin{array}{c}\text { Alcohol } \\
\text { content (V/V) }\end{array}$ & $\begin{array}{c}\text { Acidity } \\
\text { (W/V) }\end{array}$ & $\begin{array}{c}\text { Total Solids } \\
(\mathrm{W} / \mathrm{v})\end{array}$ & $\begin{array}{c}\text { Sulfated } \\
\text { ash(W/V) }\end{array}$ & Brix value & Conductivity & $\begin{array}{c}\text { Original } \\
\text { Extract }\end{array}$ \\
\hline A1 & 5.5 & 0.3 & 8.15 & 0.55 & 10 & 5.41 & 17.32 \\
\hline A2 & 7.6 & 0.45 & 4.86 & 0.51 & 5.0 & 5.78 & 17.26 \\
\hline A3 & 8.0 & 0.5 & 2.26 & 0.51 & 3.5 & 5.9 & 15.9 \\
\hline B1 & 6.5 & 0.5 & 5.13 & 0.55 & 6.5 & 5.9 & 16.2 \\
\hline B2 & 6.8 & 0.4 & 5.1 & 0.55 & 6.5 & 5.9 & 16.4 \\
\hline B3 & 7.9 & 0.5 & 4.35 & 0.49 & 5.5 & 5.37 & 17.25 \\
\hline C1 & 6.1 & 0.52 & 5.97 & 0.47 & 6.5 & 5.5 & 16.13 \\
\hline C2 & 7.1 & 0.52 & 4.13 & 0.47 & 6.0 & 5.6 & 15.67 \\
\hline C3 & 7.8 & 0.58 & 3.34 & 0.49 & 4.0 & 5.59 & 16.07 \\
\hline D1 & 6.0 & 0.66 & 6.1 & 0.47 & 6.5 & 5.35 & 15.47 \\
\hline D2 & 6.9 & 0.65 & 4.0 & 0.46 & 5.0 & 5.35 & 15.09 \\
\hline D3 & 7.1 & 0.72 & 3.3 & 0.49 & 4.0 & 5.38 & 14.4 \\
\hline
\end{tabular}

1 denoted just draw from tree, 2 denoted after 7 hours fermentation processes, 3 denoted after 12 hours fermentation processes 


\section{Appendix 3: Gas Chromatograms of Toddy}

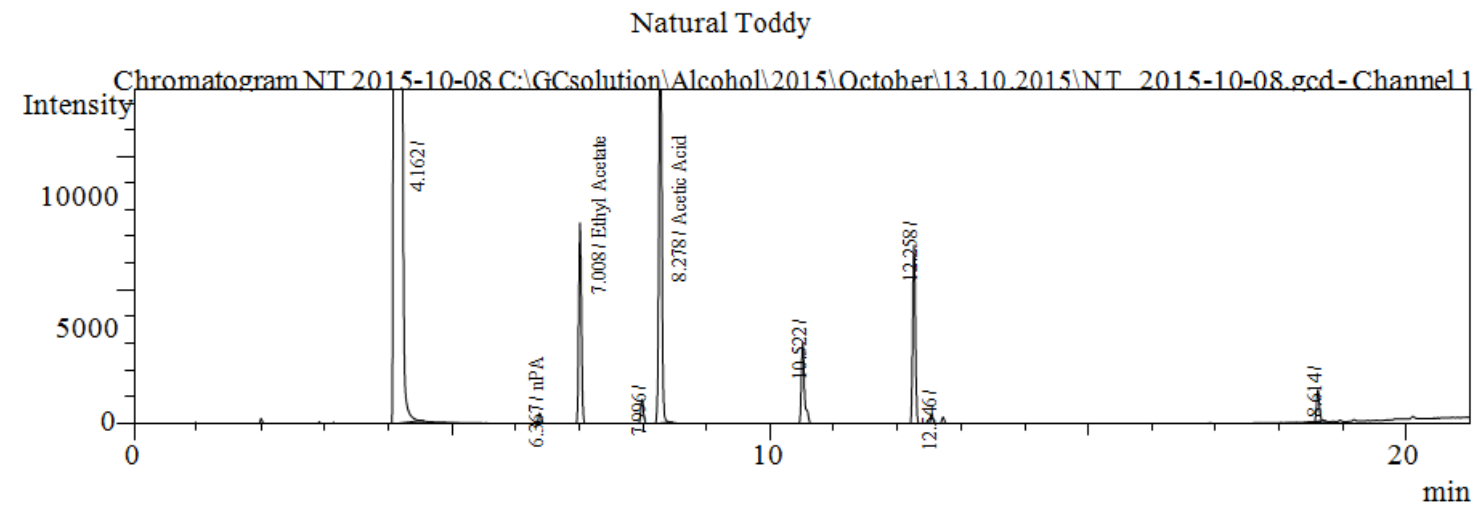

Artificial Toddy made from sugar solution fermented using natiral toddy innoculum (A)

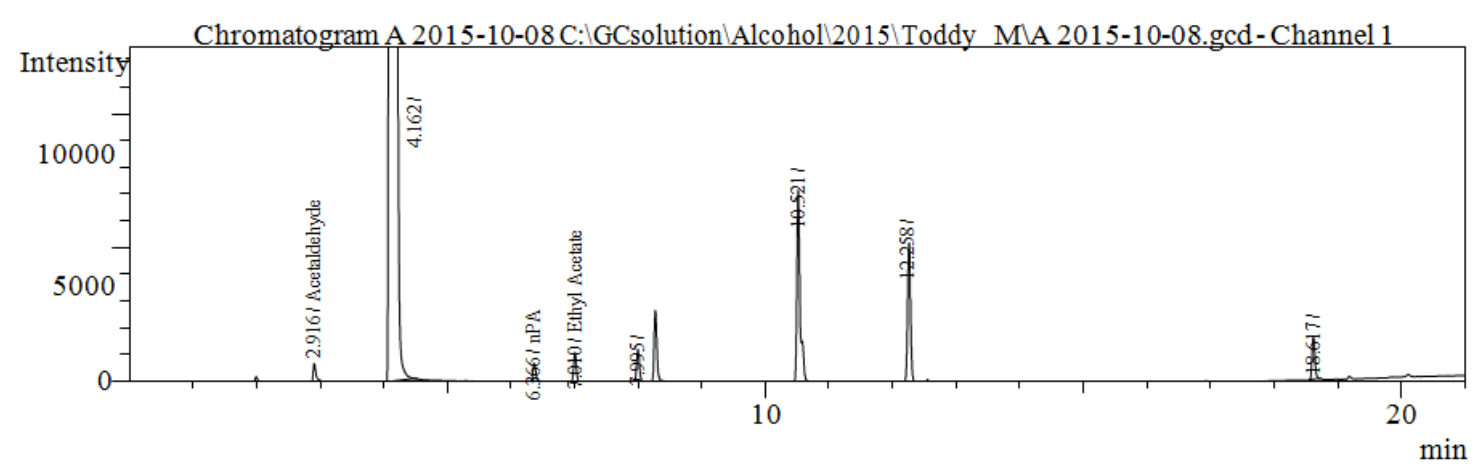

Mixture of Artificial toddy (A) and Natural toddy (1:1)

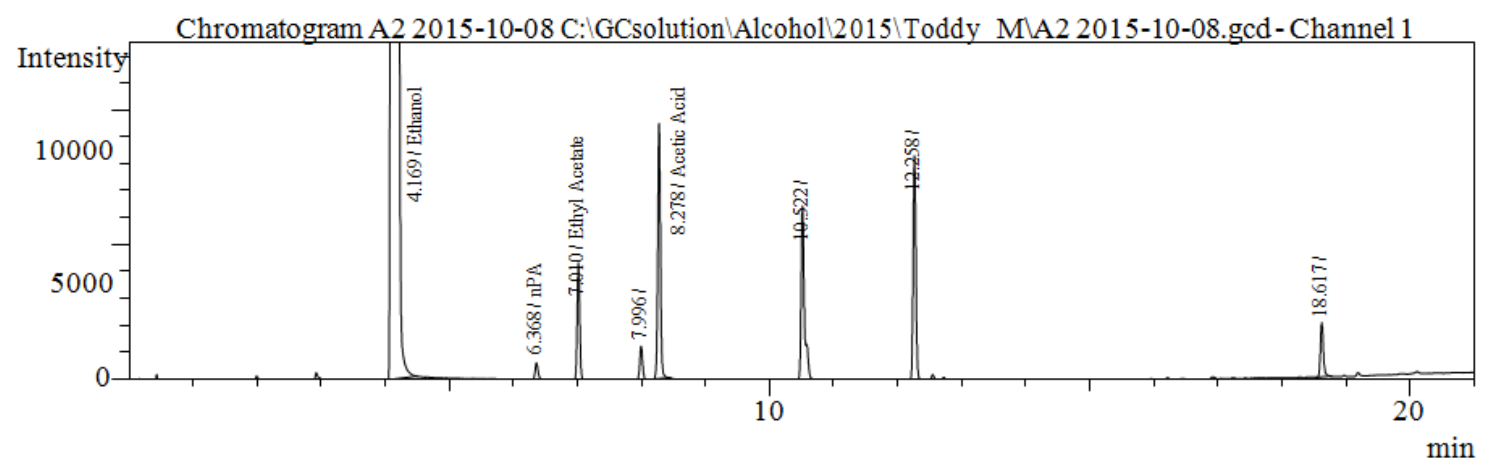

Artificial Toddy made from sugar solution fermented using Baker's yeast

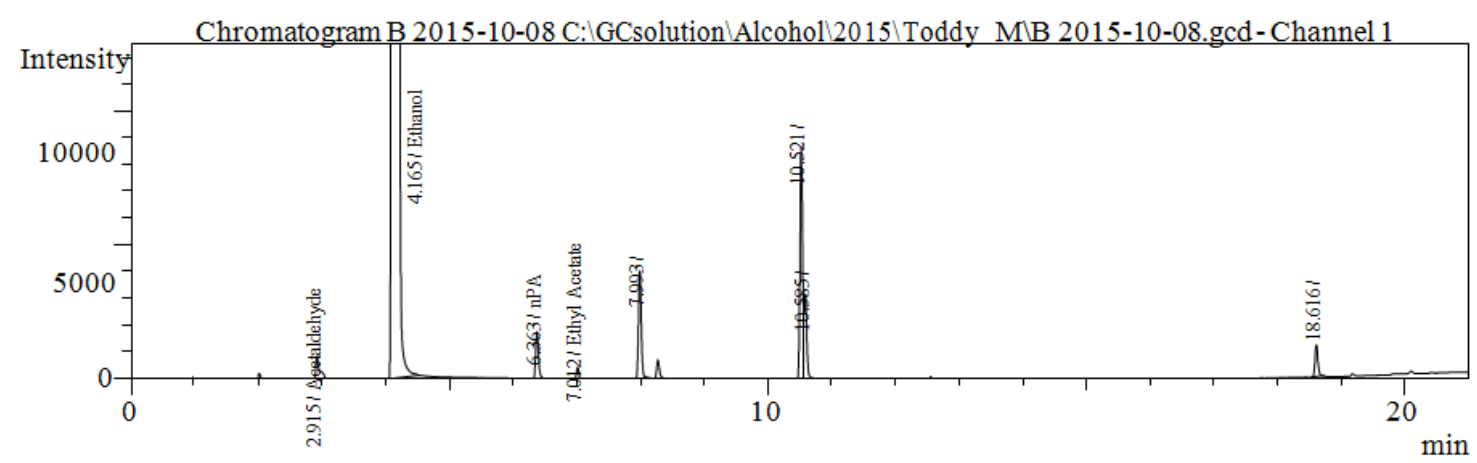




\section{REFERENCES}

[1] (C. S. Ranasinghe and W. P. K. K. Fernando, Coconut Research Institute, Lunuwila, Srilanka). Toddy: Authentic or Adulterated how do we know? http://cri.nsf.ac.lk/handle/1/916. Date: 2002.

[2] Hariharan. B, Singaravel. K, Alagusundaram. K, (2012) Physico chemical properties of fresh and stored coconut palm toddy open access scientific Report. https://www.omicsonline.org/scientific-reports/1948-5948SR-397.pdf

[3] (Qiuyu Xia, Rui Li , Songlin Zhao, Weijun Chen , Hua Chen , Bo Xin , Yulin Huang. (2011)Chemical composition chages of post- harvest coconut inflorescence sap during natural fermentation. African Journal of Biotecnology, Vol. 10 (66),pp. 1499-15005

[4] P. C. Leong, (1952) The nutritive value of Coconut Toddy (Department of chemistry, University of Malaya, Singapore.

[5] Borse B B, Rao L J M, Ramalakshmi K, Ragahavan B (2007) chemical composition of volatiles from coconut sap (neera) and effect ofprocessing. Food chem. 101(3):877-880

[6] Hand Book of fermented foods second edition revised \& expanded edited by Keith. H .Steinkarus

[7] Atputharajah J D, Widanapathirana S, Samarajeewa U (1986). Microbiology and biochemistry of natural fermentation of coconut palm sap, Food microbiology. volume 3,issue $4: 273-280$

[8] AOAC International 2012 Appendix F Guidelines for Standard Method Performance Requirements

[9] Tuley P (1965) studies on the production of wine from the oil palm.

[10] (M. J. M. Hootsmans, J. E. Vermaat, international Institute for infrastructural Hydraulic and Environmental Engineering, The Netherlands) Data analysis Statistical Processing and Graphical Presentation

[11] Sulphated ash content was determined by the method in I.S.I. Handbook of Food Analysis (Part II) - 1984 page 18. 